\title{
Changes in leptospirosis etiology in animals and humans
}

\author{
Natalia Vasylieva ${ }^{1, D-F}$, Mykhaylo Andreychyn ${ }^{2, E-F}$, Yulia Kravchuk ${ }^{3, B-C}$, Olena Chervinska ${ }^{4, B-C}$, \\ laryna losyk ${ }^{5, A, D}$ \\ ${ }^{1}$ Department of Infectious Diseases and Epidemiology, I. Ya. Horbachevsky State Medical University, Ternopil, Ukraine \\ ${ }^{2}$ Corresponding member of the National Academy of Medical Sciences of Ukraine, Department of Infectious Diseases \\ and Epidemiology, I. Ya. Horbachevsky State Medical University, Ternopil, Ukraine \\ ${ }^{3} \mathrm{SI}$ "Ternopil Regional Laboratory Centre of the Ministry of Health of Ukraine" \\ ${ }^{4}$ Ternopil State Regional Laboratory of Veterinary, Ukraine \\ ${ }^{5}$ Infectious Diseases and Epidemiology Department, I. Ya. Horbachevsky State Medical University, Ternopil, Ukraine \\ A - Research concept and design, B - Collection and/or assembly of data, C - Data analysis and interpretation, \\ $D$ - Writing the article, E-Critical revision of the article, F- Final approval of article
}

Vasylieva N, Andreychyn M, Kravchuk Y, Chervinska O, losyk I. Changes in leptospirosis etiology in animals and humans. Ann Agric Environ Med. 2017; 24(4): 671-675. doi: 10.26444/aaem/78031

\begin{abstract}
Introduction. Leptospirosis is endemic in Ternopil region. In Ukraine, the disease is registered in almost all regions, including the Ternopil region. The aim of the research is to study the regularities of epidemic and epizootic processes of leptospirosis, and the circulation of its pathogens among different sources (small mammals, animals) and humans.

Materials and method. Etiologic spectrum of leptospirosis registered in Ternopil region in 1972-2016 among small mammals, farm animals and sick people was studied.

Results. Due to the analysis of pathogens circulation among different sources (small mammals, animals), as well as the annual morbidity in humans, it was proved that new leptospira serovars are endemic and brought into the regions mostly by farm animals. Farm animals introduce the infection to humans through the environment, sometimes within 3-5-years. The spread was observed of pathogen serovars, which are new in certain areas, among all types of mouse-like small mammals and rats. It was established that livestock and small mammals are parallel reservoirs.

Conclusions. In the regions with endemic species, the structural modification in the etiology of leptospirosis in humans is caused by additional reservoirs among animals, as well as the circulation of other pathogen serovars that were absent in the main natural reservoir, i.e. mouse-like small mammals and rats. The constant monitoring of the population, contamination and carrier state of mouse-like small mammals, rats and farm animals, is required In order to predict the future epidemiological situation on leptospirosis among the population and to improve leptospirosis diagnosis.
\end{abstract}

Key words

morbidity, leptospirosis, farm animals, source of infection, small mammals

\section{INTRODUCTION}

Leptospirosis is a widespread infectious disease among both humans and animals. The infection is characterized by a predominantly severe course and high mortality, and causes significant social and economic loss. Experts estimate that annually 1.03 million patients and 58,900 deaths are registered which occur due to leptospirosis among the world population. The highest incidence and mortality is observed in South and Southeast Asia, Oceania, Latin America and East Africa [1-7].

In European countries, leptospirosis is known as an imported disease ("travellers' disease" [8-13]) or in certain occupational groups (among agricultural works, livestock and forestry workers, etc. [14-19]). In Ukraine, the disease is registered in almost all regions, including the Ternopil region.

Endemicity of the leptospirosis territories is caused primarily by the presence of the main natural reservoir of

\footnotetext{
Address for correspondence: laryna losyk, Assistant of Infectious Diseases and Epidemiology Department, I. Ya. Horbachevsky Ternopil State Medical University, Ternopil, Ukraine

e-mail: josyk.jaryna@gmail.com

Received: 26.04.2017; accepted: 27.09.2017; first published: 05.12.2017
}

pathogens - mouse-like small mammals, and also favourable natural climatic conditions (mildly alkaline and alkaline soils, sufficient rainfall, appropriate air temperature [20,21]).

The research was aimed at investigating the regularities of epidemic and epizootic processes of leptospirosis, and the circulation of its pathogens among different sources (small mammals, animals) and humans.

\section{MATERIALS AND METHOD}

The materials of the Department of Highly Infectious Diseases of the Ternopil Regional Laboratory Centre of the Ministry of Health of Ukraine, Ternopil Regional Laboratory of Veterinary Medicine, and Clinic of Infectious Diseases of Ternopil State Medical University were analysed. Leptospira was detected by dark field microscopy (DFM) of the blood of patients, small mammals and farm animals. Pathogen serovar was determined by microagglutination test (MAT) with relevant live leptospira cultures. The standard diagnostic kit consisted of 11 L. interrogans serogroups, which included both diagnostic strains proposed by the WHO and strains registered in Ukraine and identified in accordance with international reference cultures. 
The incidence of leptospirosis among the population in Ternopil region in 1972-2016, infection of animals in domestic and collective farms, as well as small mammals in the wild were studied.

\section{RESULTS AND DISCUSSION}

In Ukraine, a relatively high morbidity of leptospirosis was recorded over the last 30 years: maximum in 1998 - 1574 cases, followed by some decrease in $2014-473$ cases. Intense rates ranged from 0.55 (minimum, 1987) to 3.12 per 100 thousand people (maximum in 1998). The incidence in the country was uneven.

Regular monitoring of leptospirosis among the population of Ternopil region has been undertaken since 1972, with the incidence fluctuating by as much as $1.05-12.17$ points per 100 thousand of people (2-149 cases per year). The maximum increase was noted in 1992-2001 (5.16), the highest in 1994 (12.17), and 3.26 points in 2014. The ratios constantly exceeded the average rate in the country and for many years were the highest in Ukraine.

In the region there were also two 'swimming' outbreaks of leptospirosis (laboratory decrypted - L. grippotyphosa) among children in July 1963 (18 patients) and August 1972 (22 patients). Both happened after swimming in a river, upstream of which leptospirosis disadvantaged livestock farms were located. Small mammals near the river were contaminated with the same leptospira serovar.

The majority of cases were male (69.2\%), people of working age (in different periods from 71.5-88.1\%), and rural residents (75.7\%). The disease among the city residents was often associated with work in rural areas (suburban areas). The world literature also confirmed that the disease prevalence (2008-2012) among the rural population of Brazil was 8 times higher than in urban areas [22]. At the same time, according to data from other countries, there is a trend to greater involvement of the urban population in the epidemic process [23], especially in adverse sanitary conditions - high water, contact with sewage, etc. [24-26]. Independent risk factors for leptospirosis during the city epidemics included living near open sewage drains, the presence of rats, work exposure to pollution sources of the environment [27].

Until 1981, L. grippotyphosa was the main causative agent of leptospirosis among the population in Ternopil region (90\% of etiologically interpreted cases); in the subsequent years, the percentage of this serovar in the disease structure decreased to $41.1-51.4 \%$ (1988-1989), then to 3.4\% (1994), in 1999-2000 there were no registered cases of leptospirosis caused by this pathogen. In the 1990s, L. icterohaemorrhagiae was the main etiological factor $(1991$ - 93.2\%, $2000-$ $100.0 \%)$; rare diseases were associated with other leptospira: L. hebdomadis, L. canicola, L. pomona. From 2002, there were recorded more disease cases caused by L. hebdomadis (5.9-45.4\%), L. canicola (14.2-60.0\%), L. pomona (3.1$21.4 \%)$; L. icterohaemorrhagiae share decreased to $37.5 \%$, L. grippotyphosa cases were rare and only in some years.

The share of leptospirosis caused by different combinations of pathogen serovars has significantly increased in recent years. During the period of monitoring in Ternopil region 61 cases were registered; their part in the total incidence of leptospirosis ranged from 1.3\% (1994) - 42.9\% (1986), including $34.3 \%$ of all registered cases in 2014 . The number of similar cases over the last 10 years increased from 1-3 - 9-12 per year. The most frequent combination of different leptospira serovars are L. icterohaemorrhagiae + canicola (60.6\%), less frequent are L. icterohaemorrhagiae + grippotyphosa and L. icterohaemorrhagiae + pomona (8.2\% each), and the combination of 3 serovars was observed in 1 case $(1.6 \%)$ - L. icterohaemorrhagiae + canicola + pomona. A paired sera study proved the increase in antibody titre (by 4 times and more) of 2 pathogens simultaneously in a half of the examined people.

The literature also reports uncommon cases of leptospira combination in humans, but they are rare [28, 29]. At the same time, according to data provided by the Uzhgorod Regional Infectious Diseases Hospital, among 30 patients with leptospirosis every third was registered with 2 pathogens simultaneously, including L. icterohaemorrhagiae + canicola in 8 of 10 cases [30].

According to our data, the epidemiological features of the spread of leptospirosis in Ternopil region were closely associated with the pathogen serogroup.

The incidence caused by the Grippotyphosa serogroup was of pronounced seasonality: its highest rate was in summer and autumn months (mainly July, August and September), and was 2.5-3.7 times higher than the average level of the day and year; in winter and spring months there were rare cases. Leptospirosis caused by Icterohaemorrhagiae serogroup was registered all year-round and more evenly distributed over the year. Summer and autumn increase of morbidity was low. In recent years, summer-autumn seasonality leptospirosis still takes place, despite the fact that Grippotyphosa serogroup occurs very rarely. It is probable that the high incidence of leptospirosis caused by the Icterohaemorrhagiae serogroup among people during the whole year is due to the constant presence of leptospirosis-carrying small mammals (Rattus norvegicus, Mus musculus) in humans' habitation and business premises, especially in rural area. The contact of humans with the environment that is the habitat of these biological carriers of Grippotyphosa serogroup and other pathogens, occurs mainly while swimming, fishing, and among farm works, results in an increase in morbidity during the summer-autumn period.

During the planned epizootic survey, conducted in 19801993 by the staff of the Department of Highly Infectious Diseases of Ternopil Regional Laboratory Centre of the State Sanitation and Epidemiological Service of Ukraine, the increase in the number of mouse-like small mammals, from $2.3 \%$ (per 100 traps) in 1980 to $12.5 \%$ in 1990, was established. In natural conditions, mainly Grippotyphosa serogroup of leptospira was detected among different types of Sylvaemus flavicollis and Mus musculus (infection - 18.3-25.5\%); in the settlements only Icterohaemorrhagiae serovar was detected in the main house occupant - Rattus norvegicus (infection rate 50-58.1\%), occasionally also in Mus musculus. Before 2001, these small mammals were found in 50.4-75.0\% of the leptospirosis epidemic nursery; in 2001-2007, rodents' occupation of human leptospirosis centres decreased to $30.8 \%$. Infection of small mammals was also reduced: in vivo - to $0.5-4.75 \%$ and in the domestic nursery to isolated cases.

According to DFM + MAT, infection of small mammals is 1.6-1.9 times higher than the official figures, based only on the results of MAT. The highest rate of infection of small mammals was registered in recent years, increasing from $3.0 \%$ (2010) to $16.9 \%$ (2015). 
Although the incidence among humans in recent years is low (0.94-1.03 per 100 thousand of the population in 20152016), the spread of light forms of leptospirosis is possible because it escapes doctors' attention, or is hidden behind other medical diagnoses. Thus, during analysis of 3, 062 samples of blood serum of people participating in voluntary blood donation, 300 (9.8\%) serum samples with titre of antileptospirosis antibodies 1:80 and higher were found. Over the years (1995-2000), the share of donors with high titre of anti-leptospirosis antibodies ranged from 6.12\% (1996) to $15.33 \%$ (1995), mostly among the residents of rural areas. None of the donors in the survey had been ill previously with leptospirosis, which proves the endemicity of the region on leptospirosis.

During the first stage of observation (1981-1993), great attention was paid to the relations between leptospirosis etiological spectrum in humans and the main reservoir - mouse-like small mammals In the natural biotope of different species of Microtus arvalis, Apodemus agrarius, Mus musculus, and Microtus oeconomus, mostly antibodies related to leptospira of Grippotyphosa serogroup were detected; in the main inhabitant of house environment Rattus norvegicus - only Icterohaemorrhagiae. In Sylvaemus flavicollis and a Mus musculus, Hebdomadis was also detected, in the home environment. During that period, some people were registered as ill with the pathogens listed above, as well as with Canicola and Pomona (1982), followed by Kabura (2005) and Polonica (2007), which were not detected in small mammals. A case of leptospirosis in humans was also registered in 2010, caused by L. australis; the infection could possibly have happened in the other regions, although the source of the infection was not defined.

Farm animals are also considered to be a source of leptospirosis infection for humans [31-33]. However, some authors consider that farm animals are not especially critical for the leptospirosis epidemiology in most regions because rats are mostly detected in disease focus areas [34].

There are many cases of leptospirosis serologically positive farm animals in domestic and collective farms (Tab. 1).

Table 1. Results of serological investigation of farm animals for leptospirosis and serovar of the registered pathogens (2001-2016)

\begin{tabular}{|c|c|c|c|}
\hline \multirow{3}{*}{ Source and type of agent } & $2001-2005$ & 2006-2010 & 2011-2016 \\
\hline & \multicolumn{3}{|c|}{ Examined/Seropositive } \\
\hline & $108151 / 2465$ & $109618 / 1413$ & $58694 / 943$ \\
\hline Infection percent & 2.28 & 1.29 & 1.61 \\
\hline Seropositive: cattle & 1294 (1.62 \%) & $681(0.88 \%)$ & $387(1.73 \%)$ \\
\hline pigs & 1110 (4.06 \%) & $538(1.80 \%)$ & 342 (0.99\%) \\
\hline horses & $61(5.40 \%)$ & $194(7.87 \%)$ & $214(11.99 \%)$ \\
\hline L. icterohaemorrhagiae & 1186 (48.1%) & $157(11.1 \%)$ & $239(25.3 \%)$ \\
\hline L. pomona & $116(4.7 \%)$ & $29(2.0 \%)$ & 40 (4.2 \%) \\
\hline L. grippotyphosa & $48(1.9 \%)$ & $61(4.3 \%)$ & $76(8.1 \%)$ \\
\hline L. tarassovi & $35(1.4 \%)$ & $6(0.4 \%)$ & $3(0.3 \%)$ \\
\hline L. kabura & $95(3.9 \%)$ & $185(13.1 \%)$ & $60(6.4 \%)$ \\
\hline L. polonica & $281(11.4 \%)$ & $173(12.2 \%)$ & $62(6.6 \%)$ \\
\hline L. hebdomadis & $22(0.9 \%)$ & $12(0.8 \%)$ & \\
\hline L. bratislava & & $231(16.3 \%)$ & 79 (8.4 \%) \\
\hline L. canicola & & $11(0.8 \%)$ & $23(2.4 \%)$ \\
\hline Combined & $682(27.7 \%)$ & $404(28.6 \%)$ & $218(23.1 \%)$ \\
\hline
\end{tabular}

The etiological structure of animal leptospirosis is different and comprises L. icterohaemorrhagae, pomona, grippotyphosa, hebdomadis, polonica, canicola, kabura, tarassovi. L. bratislava has been registered since 2007 (87.5\% in pigs in 2008). Often diagnostically significant titers of antibodies up to 2 different serovars were registered simultaneously (71.4-78.0\% in cattle, 2003-2006). Any dependence on the relevant pathogens serovar in different years and in different farm animals was not established. For instance, in 2016, L. kabura and polonica alone and in combinations $(61.1 \%$ each) prevailed in positively reactive cattle, and L. icterohaemorrhagiae accounted for 83.9-94.8\% in pigs in 2015-2016.

The seropositivity of farm animals may be caused by vaccination, their natural infection with the disease $1.8 \%$ of farm animals were leptospira seropositive $3.8 \%$ in 2009 and $0.8 \%$ in 2014). In 2008-2016, the seropositivity rate among cattle ranged from $0.2-2.4 \%$ of the number of the examined, horses $-8.2-14.4 \%$, pigs $-0.4-3.2 \%$. The seropositivity may have been caused by vaccination, although there is no L. kabura, L. hebdomadis, L. bratislava in animal vaccines; for that reason, their seropositivity is obviously not associated with vaccination, but due to natural infection or previous disease.

Leptospira-carriage and cases of infection among farm animals at home and on collective farms were registered in Ternopil region every year, and these cases increased the rate of animal mortality and abortions rate, but from 1983 epizootic diseases were rare. However, the antibodies were defined in quite high titres (1:400), which allows speaking of carriage or a subclinical form of the disease in animals, and considering them as potential sources of leptospirosis in humans. The possibility of farm animal infection at livestock replenishing from other farms and other areas cannot be excluded.

According to the literature, the duration of leptospiracarriage has been established in cattle for up to 6 months and among pigs - up to 1 year; nevertheless, up to $10 \%$ of cattle and $30 \%$ of pigs remain carriers for life, as well as rats and mice [31].

Until 1993 in Ternopil region, only leptospira of Grippotyphosa and Icterohaemorrhagiae, and rarely Hebdomadis serogroups, were detected in small mammals, followed by the identification of antibodies to other serovars: Canicola among rats (2004), Kabura (2006) among house mice; among different vole species, with the exception of Grippotyphosa, there were also Icterohaemorrhagiae, Pomona, Canicola and Hebdomadis, which means that there was an expansion of the pathogens spectrum and their subsequent distribution among all types of the examined mouse-like small mammals (Tab. 2). In 2015, leptospira Polonica was registered among small mammals for the first time.

The presented analysis and previous researches by the authors [35, 36] allow them to state the association between human diseases and the incidence of appropriate leptospira serovars in farm animals because these pathogens were not previously registered among mouse-like small mammals and rats in the region. New leptospira serovariants are spread mostly by farm animals; they cause the introduction of infection in humans through the environment, registered in the population mainly 3-5 years after their registration among animals. The further spread is observed of pathogen 
Table 2. Small mammals species in natural habitats and settlements and their infection with different leptospira serogroups (1981-2016)

\begin{tabular}{|c|c|c|c|c|c|c|c|c|c|}
\hline \multirow{3}{*}{ Small mammals species } & \multicolumn{9}{|c|}{ Registered antibodies to leptospira serogroups } \\
\hline & \multicolumn{3}{|c|}{ 1981-1993 } & \multicolumn{3}{|c|}{$2001-2007$} & \multicolumn{3}{|c|}{ 2010-2016 } \\
\hline & $n$ & $\%$ of infected & leptospira serovars & $n$ & $\%$ of infected & leptospira serovars & $n$ & $\%$ of infected & leptospira serovars \\
\hline Microtus arvalis & 1685 & 30.33 & $g r$ & 34 & 14.71 & DFM & 274 & 14.96 & ict, gr, pom, can, hebd \\
\hline Clethrionomys glareolus & 326 & 27.91 & $g r$ & 72 & 6.94 & hebd & 115 & 16.52 & ict, gr, pom, can, hebd \\
\hline Sylvaemus flavicollis & 190 & 41.05 & gr, hebd & 33 & 3.03 & DFM & 132 & 26.52 & ict, gr, pom, can, hebd \\
\hline Soricidae & 5 & 100.0 & $g r$ & 2 & - & & - & & \\
\hline Apodemus agrarius & 12 & 8.33 & $g r$ & 49 & - & & 199 & 20.60 & ict, gr, pom, can, hebd \\
\hline Mus musculus & 126 & 35.71 & gr, hebd, ict & 1814 & 1.38 & hebd, ict, can, kabura & 1489 & 3.16 & ict, gr, pom, can, hebd \\
\hline Microtus oeconomus & 22 & 100.0 & $g r$ & - & - & & - & & \\
\hline Rattus norvegicus & 1016 & 33.96 & $i c t$ & 475 & 3.58 & $i c t, c a n$ & 278 & 5.76 & ict, gr, hebd, polonica \\
\hline Sylvaemus sylvaticus & - & & & 5 & & & 39 & 69.23 & pom, can, ict \\
\hline Total & 3392 & 33.14 & & 2484 & 2.09 & & 2541 & 12.55 & \\
\hline
\end{tabular}

ict-Icterohaemorrhagiae; gr-Grippotyphosa; pom - Pomona; can-Canicola; hebd-Hebdomadis; kabura - Kabura; polonica-Polonica.

serovars which are new in certain regions among all types of the examined mouse-like small mammals and rats.

Therefore, it was established that cattle and small mammals are parallel reservoirs of leptospirosis pathogens. To predict the future epidemiological situation for leptospirosis among the population and to improve its diagnosis, the constant monitoring of the population, contamination and carrier state in mouse-like small mammals, rats and farm animals, as well as expanding the range of diagnostic leptospira strains with new pathogens among animals are necessary.

The serologically-defined range of pathogens was compared during the observation of humans, farm animals and small mammals and rats (Tab. 3). Thus, the factors that ensure the evolution of the epidemic process in leptospirosis are: changes in the main natural reservoir - rodent species, their number and infection rate; spread of new strains of leptospira into endemic areas by farm animals, which cause introduction of the infection to humans through the environment, followed by the further spread of leptospira strains among small mammals and rats, as well as pathogen development.

Preventive measures are: annual examination for leptospirosis of breeding stock of cows and animals for sale to other farms; sanitation of animals-carriers against leptospira; vaccination; deratisation; draining of wetlands. Taking these measures allows reducing (probably avoiding)

Table 3. First registration of leptospira serovars serologically detected in humans, farm animals and small mammals in the region (1972-2016)

\begin{tabular}{lcc}
\hline Small mammals & Farm animals & Humans \\
\hline $\begin{array}{l}\text { L. icterohaemorrhagiae } \\
\text { (1972) }\end{array}$ & $\begin{array}{c}\text { L. icterohaemorrhagiae } \\
(1972)\end{array}$ & $\begin{array}{c}\text { L. icterohaemorrhagiae } \\
\text { (1972) }\end{array}$ \\
\hline L. grippotyphosa (1972) & L. grippotyphosa (1972) & L. grippotyphosa (1972) \\
\hline L. hebdomadis (1983) & L. hebdomadis (1981) & L. hebdomadis (1981) \\
\hline L. canicola $(1982,2004)$ & L. canicola (1979) & L. canicola (1982) \\
\hline L.pomona $(2008)$ & L. pomona (1979) & L. pomona (1982) \\
\hline L. kabura (2006) & L. kabura (2002) & L. kabura (2005) \\
\hline L.polonica (2015) & L.polonica (2002) & L. polonica (2007) \\
\hline & L. tarassovi (2002) & \\
\hline & L. bratislava (2007) & L. australis (2010)
\end{tabular}

the spread of new leptospira strains into endemic areas and preventing morbidity [31].

\section{CONCLUSIONS}

1. In endemic territories, the structural modification in etiology of leptospirosis in humans is caused by additional reservoirs among animals, together with circulation of other pathogen serovars that were absent in the main natural reservoir, i.e. mouse-like small mammals and rats.

2. Increase of the pathogens spectrum in cases of leptospirosis incidence among the population was evidenced during the research. The further spread of these pathogens among all species of the examined small mammals was also proved. 3. The results of leptospirosis pathogens detection among the studied groups prove that farm animals and small mammals are parallel reservoirs that cause introduction of the infection to humans through the environment.

\section{REFERENCES}

1. Leptospirosis, India. Report of the investigation of a post-cyclone outbreak in Orissa, November 1999. Wkly Epidemiol Rec. 2000; 75(27): 217-223.

2. Levett PN. Leptospirosis. Clin Microbiol Rev. 2001; 14(2): 296-326.

3. Schoonman L, Swai ES. Risk factors associated with the seroprevalence of leptospirosis, amongst at-risk groups in and around Tanga city, Tanzania. Ann Trop Med Parasitol. 2009; 103(8): 711-718.

4. Adesiyun AA, Baboolal S, Suepaul S, Dookeran S, Stewart-Johnson A. Humans leptospirosis in the Caribbean, 1997-2005: characteristics and serotyping of clinical samples from 14 countries. Rev Panam Salud Publica. 2011; 29(5): 350-357.

5. Goswami RP, Goswami RP, Basu A, Tripathi SK, Chakrabarti S, Chattopadhyay I. Predictors of mortality in leptospirosis: an observational study from two hospitals in Kolkata, eastern India. Trans R Soc Trop Med Hyg. 2014; 108(12): 791-796.

6. Massenet D, Yvon JF, Couteaux C, Goarant C. An Unprecedented High Incidence of Leptospirosis in Futuna, South Pacific, 2004-2014, Evidenced by Retrospective Analysis of Surveillance Data. PLoS One. 2015; 10(11):e0142063. doi: 10.1371/journal.pone.0142063. eCollection 2015.

7. Costa F, Hagan JE, Calcagno J, Kane M, Torgerson P, Martinez-Silveira MS et al. Global Morbidity and Mortality of Leptospirosis: A Systematic 
Review. PLoS Negl Trop Dis. 2015; 9(9): e0003898. doi: 10.1371/journal. pntd. 0003898 .

8. Van Crevel R, Speelman P, Gravekamp C, Terpstra WJ. Leptospirosis in travelers. Clin Infect Dis 1994; 19(1): 132-134.

9. Ricaldi JN, Vinetz JM. Leptospirosis in the tropics and in travelers. Curr Infect Dis Rep. 2006; 8(1): 51-58.

10. Hoffmeister B, Peyerl-Hoffmann G, Pischke S, Zollner-Schwetz I, Krause R, Müller MC, et al. Differences in clinical manifestations of imported versus autochthonous leptospirosis in Austria and Germany. Am J Trop Med Hyg. 2010; 83(2): 326-335.

11. Leshem E, Segal G, Barnea A, Yitzhaki S, Ostfeld I, Pitlik S, et al. Travel-related leptospirosis in Israel: a nationwide study. Am J Trop Med Hyg. 2010; 82(3): 459-463.

12. Bandara M, Ananda M, Wickramage K, Berger E, Agampodi S. Globalization of leptospirosis through travel and migration. Global Health. 2014; 10: 61 .

13. Pagès F, Kuli B, Moiton MP, Goarant C, Jaffar-Bandjee MC. Leptospirosis after a stay in Madagascar. J Travel Med. 2015; 22(2): 136-139.

14. Belmaker I, Alkan M, Barnea A, Dukhan L, Yitzhaki S, Gross E. Risk of transmission of leptospirosis from infected cattle to dairy workers in southern Israel. Isr Med Assoc J. 2004; 6(1): 24-27.

15. Colavita G, Paoletti M. Leptospirosis: occupational risk in the chain of food of animal origin. G Ital Med Lav. Ergon. 2007; 29(1): 21-24.

16. Bakoss P, Macháčová E, Jareková J. Long-term trends in the epidemiology of humans leptospirosis (Slovak Republic, 1954-2006). Eur J Clin Microbiol Infect Dis. 2012; 31(9): 2167-2176.

17. Fiecek B, Grochowalska A, Chmielewski T, Tylewska-Wierzbanowska S Leptospira spp. and Coxiella burnetii infections occuring in Radomskie District in people of selected professional groups. Przegl Epidemiol. 2012; 66(4): 605-610.

18. Richard S, Oppliger A. Zoonotic occupational diseases in forestry workers - Lyme borreliosis, tularemia and leptospirosis in Europe. Ann Agric Environ Med. 2015; 22(1): 43-50.

19. Papa A, Kotrotsiou T. Leptospirosis in Greece. Acta Trop. 2015;149:135137. doi: 10.1016/j.actatropica.2015.05.025.

20. Vynograd NO, Kiriyak OP, Murzova LI, Volos IV. Ecological and epidemiological features of leptospirosis in Ivano-Frankivsk. Modern infection. 2004; 1: 60-65.

21. Kravchuk YA, Vasylieva NA. Epizootic and epidemiology features for leptospirosis in Ternopil region. Annals of Mechnykov Institute. 2015; 2 : 165-171.

22. Schneider MC, Najera P, Pereira MM, Machado G, Dos Anjos CB, Rodrigues RO, et al. Leptospirosis in Rio Grande do Sul, Brazil: An Ecosystem Approach in the Animal-Human Interface. PLoS Negl Trop Dis. 2015; 9(11): e0004095. doi: 10.1371/journal.pntd.0004095.
23. Ariyapruchya B, Sungkanuparph S, Dumrongkitchaiporn S. Clinical presentation and medical complication in 59 cases of laboratoryconfirmed leptospirosis in Bangkok. Southeast Asian J Trop Med Public Health. 2003; 34(1): 159-164.

24. Ko AI, Galvao Reis M, Ribeiro Dourado CM. Johnson Jr WD, Riley LW. Urban epidemic of severe leptospirosis in Brazil. Lancet. 1999; 354(9181): 820-825.

25. Diaz JH. Recognition and management of rodent-borne infectious disease outbreaks after heavy rainfall and flooding. J La State Med Soc. $2014 ; 166(5)$ : 186-192.

26. Haake DA, Levett PN. Leptospirosis in humans. Curr Top Microbiol Immunol. 2015; 387: 65-97.

27. Sarkar U, Nascimento SF, Barbosa R, Martins R, Nuevo H, Kalafanos I, et al. Population-based case-control investigation of risk factors for leptospirosis during an urban epidemic. Am J Trop Med Hyg. 2002; 66(5): 605-610.

28. Boonpucknavig V, Douangchawee G, Niwattaykul K. Infectious Diseases and Tropical Disease Pathology: SY16-2A Pathology of leptospirosis: autopsy study. Pathology. 2014; 46 (Suppl. 2): 27.

29. Babic-Erceg A, Karlovic-Martinkovic D, Santini M, Persic Z, VilibicCavlek T. Early diagnosis of leptospirosis. Infect Dis Rep. 2014; 6(2): 5156.

30. Burkalo TV. Clinical characteristics of leptospirosis in Zakarpattya. Modern infection. 2004; 1: 66-71.

31. Zadorozhna VI, Protas SV, Hopko NV, Ruban OM, Mandygra MS, Nychyk SA, et al. Epizootological and epidemiological aspects of leptospirosis in Ukraine. K., 2014.

32. Director A, Penna B, Hamond C, Loureiro AP, Martins G, Medeiros $\mathrm{M}$, et al. Isolation of Leptospira interrogans Hardjoprajitno from vaginal fluid of a clinically healthy ewe suggests potential for venereal transmission. J Med Microbiol. 2014; pii: jmm.0.065466-0. doi: 10.1099/ jmm.0.065466-0.

33. Arteaga-Troncoso G, Jiménez-Estrada JM, Montes DE, Oca-Jimenez R, López-Hurtado M, Luna-Alvarez M, et al. Seroprevalence and risk factors associated with within-flock transmission of Leptospira interrogans in transhumant farming systems in Mexico. Epidemiol Infect. 2015; Jan 20:1-9. [Epub ahead of print].

34. Bernasovskaya EP, Ugryumov BL, Vovk AD, Mohyreva LA. Leptospirosis. K. Health 1989.

35. Vasylieva NA, Burtnyak TV, Blazhkevych BV, Grusina LO. Leptospirosis humans morbidity and small mammals pathogenic leptospira contamination in the Ternopil region. Infectious diseases. 1995; 2: 22-25.

36. Vasylieva NA, Lutsuk OS, Pavliv OV. The evolution of the epidemic process of leptospirosis (the material in the Ternopil region). Preventive Medicine. 2011; 2: 69-73. 